\title{
EKSISTENSI PENYULUH AGAMA BUDDHA DALAM MEMPERTAHANKAN KEYAKINAN UMAT BUDDHA DI VIHARA MAITRI RATNA DUSUN BEDUG DESA GEDONGREJO KECAMATAN GIRIWOYO KABUPATEN WONOGIRI JAWA TENGAH
}

\author{
Suharno $^{1}$ \\ Hariyanto, S.Ag., M.Pd. ${ }^{2}$ \\ Ngadat, M.Pd.B. ${ }^{3}$
}

\begin{abstract}
Abstrak
Penelitian ini bertujuan mendeskripsikan eksistensi penyuluh agama Buddha dalam mempertahankan keyakinan umat di Vihara Maitri Ratna Dusun Bedug, Desa Gedongrejo, Kecamatan Giriwoyo Kabupaten Wonogiri. Objek penelitian adalah penyuluh Agama Buddha Penelitian ini menggunakan metode penelitian kualitatif. Teknik pengumpulan data berasal dari wawancara dan observasi. Teknik analisis data yang digunakan adalah model interaktif yang mengklasifikasikan analisis data dalam tiga langkah yaitu reduksi, penyajian, dan penarikan simpulan. Hasil penelitian menunjukkan bahwa eksistensi penyuluh agama Buddha sangat dibutuhkan oleh masyarakat Buddha. Eksistensi penyuluh sebagai penggerak umat atau motivasi dalam mempertahankan keyakinan ajaran Buddha Dhamma. Seorang penyuluh memiliki tiga komponen penting dalam fungsi dan perannya sebagai seorang penyuluh, yaitu menggerakkan, mengarahkan, dan menopang tingkah laku manusia. Kompetensi penyuluh agama Buddha sangat membantu dalam pengetahuan dan wawasan umat Buddha.
\end{abstract}

Kata Kunci: Eksistensi, Penyuluah Agama Buddha, Mempertahankan Keyakinan

\begin{abstract}
This study aims to describe the existence of Buddhist extension agents in maintaining the beliefs of the people in Maitri Ratna Vihara, Bedug Hamlet, Gedongrejo Village, Giriwoyo District, Wonogiri Regency. The object of research is the Buddhist instructor. This research uses qualitative research methods. Data collection techniques derived from interviews and observations. Data analysis technique used is an interactive model that classifies data analysis in three steps, namely reduction, presentation, and drawing conclusions. The results showed that the existence of Buddhist instructors was very much needed by the Buddhist community. The existence of instructors as mobilizers of the people or motivation in maintaining the beliefs of the Buddha's Dhamma teachings. A counselor has three important components in his function and role as an instructor, namely moving, directing, and sustaining human behavior. The competency of Buddhist instructors is very helpful in the knowledge and insight of Buddhists.
\end{abstract}

Keywords: Existence, Worship of Buddhism, Maintaining Faith

\footnotetext{
${ }^{1}$ Dharmadutta STABN Raden Wijaya, email: suharno@gmail.com

${ }^{2}$ Dosen STABN Raden Wijaya, email: hariyanto@radenwijaya.ac.id

${ }^{3}$ Dosen STABN Raden Wijaya, email: ngadat.stabn.wonogiri@gmail.com
} 


\section{Pendahuluan}

Usaha menyebarkan Dhamma setelah Sang Buddha mencapai penerangan sempurna telah dilakukan oleh Sang Buddha untuk pertama kali kepada lima orang pertapa di Isipatana. Kelima orang pertapa tersebut adalah Asaji, Mahanama, Baddhiya, Kondana, dan Vappa. Lima orang pertapa melanjutkan misi untuk menyebarkan ajaran Buddha kepada semua orang ke semua penjuru arah yang selanjutnya akan menjadi muridmuridnya yang dilakukan dengan cara ceramah secara lisan atau dalam istilah bahasa jawa disebut gethok-tular (Widyadharma, 1979: 42). Usaha tersebut dilakukan dengan tujuan agar umat Buddha memiliki keyakinan (Saddha) pada ajaran Buddha. keyakinan dalam Buddhisme harus mengandung tiga unsur yang penting seperti yang disampaikan oleh Asanga seorang pujangga Buddhis terkemuka dalam Semedha Widyadharma (1980 : 12) yang menyatakan bahwa yang menyebutkan keyakinan akan suatu hal, kegembiraan yang mendalam terhadap sifat-sifat baik, dan harapan untuk memperoleh sesuatu di kemudian hari.

Peran para penyuluh agama khususnya agama Buddha adalah untuk meningkatkan keyakinan umat. Selain itu penyuluh memiliki tugas untuk membantu perkembangan dan kemajuan umat Buddha. Pelaksanaan tugas dalam penyebaran ajaran agama secara resmi dilaksanakan oleh Kementerian Agama melalui bimbingan masyarakat masing-masing agama. Penyebaran ajaran Buddha khususnya dilaksanakan oleh
Bimas/bimbingan masyarakat Buddha yang dipimpin oleh seorang Direktur Jenderal. Secara khusus Bimas Buddha memberikan tugas kepada penyuluh agama untuk menyebarkan agama Buddha melalui surat keputusan oleh Dirjen Bimas Buddha.

Keberadaan atau eksistensi seorang penyuluh sangat dibutuhkan oleh masyarakat umat Buddha guna membantu masyarakat dalam meningkatkan keyakinan dan mempertahankan ajaran Buddhis di masyarakat. Berdasarkan hasil observasi yang dilakukan oleh peneliti pada tanggal 09 Januari 2016 di Dusun Bedog, Desa Gedongrejo, Kecamatan Giriwoyo Kabupaten Wonogiri diperoleh informasi bahwa eksistensi penyuluh agama Buddha belum maksimal. Kurang maksimalnya penyuluh agama Buddha di Wilayah tersebut dikarenakan hanya ada satu orang yang ditugaskan menjadi penyuluh hal tersebut mengakibatkan umat kurang tertarik dan merasa bosan. Melihat kondisi tersebut masyarakat umat Buddha di Vihara Maitri Dusun Gedongrejo Kecamatan Giriwoyo Wonogiri Jawa Tengah mengharapkan adanya bantuan dari daerah lain utuk membantu penyuluhan di Vihara tersebut.

Perkembangan seseorang dipengaruhi eksistensinya dalam kehidupan bermasyarakat. Eksistensi manusia berkaitan erat dengan hubungan sosial kemasyarakatan. Selaras dengan hal tersebut Menurut N, Driyarkara S.J 
menjelaskan tentang sifat dasar eksistensi manusia adalah sebagai berikut:

Pada hakikatnya manusia bukanlah makhluk yang berada sendirinya di dunia ini, karena itu hakekat manusia hanya dapat diketahui berkat bubungannya dan dilihat dalam hubungannya dengan: 1)sehat jasmani (hubungan ke bawah), 2) sesamanya (hubungan mendatar, horisontal), dan Tuhan (hubungan ke atas transendental) (Lanur, 1988: 222).

Pengertian di atas menunjukkan bahwa setiap manusia memiliki hubungan dengan sehatnya jasmani seseorang atau dengan kata lain berhubungan dengan diri sendiri. Selanjutnya eksistensi sifat dasar manusia berhubungan dengan sesama dan lingkungan serta hubungannya dengan Tuhan. Kondisi demikian dapat diartikan bahwa pada dasarnya bahwa manusia yang memiliki sifat-sifat tersebut dapat dikatakan ada keberadaannya. Sifat dasar manusia dalam dalam eksistensinya sebagai makhluk hidup tidak dapat dipisahkan antara satu dengan yang lainnya. Hal tersebut dikarenakan manusia sebagai orang dikatakan sehat jasmani adalah orang yang mampu berinteraksi dengan lingkungan sesamanya. Hasil interaksi dengan lingkungan sebagai bentuk hubungan dengan manusia dengan Tuhan Yang Maha Esa.

Keyakinan adalah kepercayaan yang tidak berbelah lagi. Keyakinan dapat diartikan sebagai tekad yang untuk yang tidak dapat terpisahkan dalam pribadi seseorang. Sama halnya dengan yang diungkapan oleh Taidin Suhaimin bahwa keyakinan sebagai bentuk bahwa dirinya boleh mengendalikan kehidupannya dengan baik serta segala cabaran yang dihadapi dengan jayanya (Taidin Suhaimin, 2015: 10). Keyakinan di dalam agama Buddha dinamakan saddha yang artinya iman atau kepercayaan berdasarkan kebijaksanan. Keyakinan yang telah diajarkan oleh Buddha yaitu sebagai kebenaran yang mutlak yang berlaku secara universal. Hal tersebut dikarenakan dapat direalisasikan melalui usahausaha tekun dan tekad yang kuat. Seseorang yang kuat dalam keyakinan tetapi lemah dalam kebijaksanaan akan memiliki keyakinan yang fanatik dan tanpa dasar. Seseorang yang kuat di dalam kebijakanaan tetapi lemah dalam keyakinan akan mengetahui bahwa orang lain bersalah jika berbuat kejahatan, tetapi sulit untuk menyembuhkannya bagaikan seorang yang penyakitnya disebabkan oleh si obat sendiri. Bila keduanya seimbang, seseorang akan memiliki keyakinan hanya bila dasarnya (Mukti, 2003: $30)$.

Penyuluh dalam agama Buddha secara khusus disebut sebagai Dhammaduta. Kegiatan Dhammaduta secara umum bertujuan untuk menyebarkan Dhamma ke seluruh penjuru dunia. Hal tersebut bertujuan agar Dhamma tetap lestari dan agama Buddha dapat berkembang. Dhamma yang disebarkan Dhammadūta diharapkan dapat membawa manfaat untuk 
kebahagian dan kesejahteraan semua makluk, sehingga terbebas dari penderitaan. Buddha menjelaskan tentang pentingnya Dhamma untuk disebarluaskan dalam Mahavagga, Vinaya Pitaka (Horner, 2000: 28) bahwa:

"Jalan, para bhikkhu, di perjalanan untuk kebaikan orang banyak, untuk kebahagiaan semua makluk yang bersedih di dunia, untuk kesejahteraan dan kebahagiaan dewa dan manusia.Janganlah, kalian pergi dengan satu arah.Para bhikkhu, ajarkanlah Dhamma yang indah pada awalnya, indah pada pertengahannya, indah pada akhirnya.Jelaskanlah dengan semangat dan ... secara keseluruhan. Terdapat makhlukmakhluk dengan sedikit debu di mata mereka, siapa yang tidak mendengar dhamma, maka akan hancur, tetapi jika mereka mendengarkan Dhamma , mereka akan berkembang."

Kutipan di atas, Buddha menganjurkan para Bhikkhu untuk mengajarkan Dhamma dengan tidak pergi ke satu arah, artinya Buddha menganjurkan supaya para bhikkhu dapat berpencar untuk menyebarkan Dhamma. Hal tersebut bertujuan agar semua orang dapat berkesampatan untuk mendengar Dhamma yang indah pada awalnya, indah pada pertengahannya, dan indah pada akhirnya. Buddha menjelaskan bahwa orang yang masih memiliki kekotoran batin dan tidak mempunyai kesempatan untuk mendengarkan Dhamma, maka seseorang akan hancur, tetapi ketika seseorang masih mempunyai kesempatan untuk mendengarkan Dhamma, maka seseorang akan berkembang batinnya. Dengan demikian, Dhammadūta sebagai orang yang mempunyai tugas menyebarkan Buddha Dhamma diharapkan dapat menyebarkan dan mengajarkan Dhamma ke seluruh penjuru dunia agar umat Buddha dapat berkesempatan untuk mendengarkan atau mengenal Dhamma, sehingga Dhamma tetap lestari dan agama Buddha dapat berkembang serta tersebar secara luas.

Penyuluhan agama merupakan satu rangkaian kegiatan atau proses dalam rangka mencapai tujuan tertentu. Bagi proses penyuluhan agama tujuan merupakan salah satu faktor yang penting dan sentral, yang memberi arah atau pedoman bagi langkah aktivitas penyuluhan. Beberapa tujuan operasonal yang dirumuskan dan menjadi dasar pijakan penyuluh adalah a) Sikap yang anti pati berubah menjadi simpati, b) sikap yang ragu berubah menjadi yakin, c) sikap yang mulai yakin berubah menjadi lebih yakin, d) tingkah laku yang malas dan acuh tak acuh berubah menjadi rajin dan antusias baik dalam pelaksanaan ibadah, e) dari rasa keterpaksaan berubah menjadi kesadaran dan keinsyafan pribadi serta timbul rasa memiliki, f) tingkah laku yang sudah rajin teratur meningkat secara kwalitatif (dari kuantitas ke kualitas), g) memelihara sikap dan tingkah laku yang sudah dihasilkan sebelumnya agar tidak mundur 
kembali (memelihara kontinuitas), h) sikap dari semula menerima penyuluhan berubah secara kwalitatif menjadi pemberi penyuluhan. I) dari pemberi penyuluhan meningkat menjadi penanggung jawab penyuluhan dan kelangsungan penyuluhan (M. Daud, 2015: 4).

Peran penyuluh agama Buddha adalah sebagai penerus dari Buddha itu sendiri. Dikatakan sebagai penerus Ajaran Buddha disebabkan seorang penyuluh agama Buddha membantu menyiarkan agama Buddha langsung kepada masyarakat. Selain itu penyuluh agama Buddhadanumatselalu menjaga dan mempertahankan ajaran agama Buddha hingga sampai saat ini tetap lestari. Sri Dhammananda menjelaskan bahwa, setiap individu harus mampu mengembangkan pemahaman dan pengelihatan oleh dirinya sendiri dengan menggunakan ajaran sebagai panduan (Ehipassiko) Dhammananda (2003: 64). Berdasarkan pada penjelasan di atas, maka dapat dikatakan bahwa seorang penyuluh agama Buddha adalah sebagai penunjuk dan pembawa Dhamma (ajaran Kebenaran) kepada masyarakat umat Buddha sekaligus sebagai motivasi untuk mempertahankan keyakinan umat.

Selanjutnya menurut peraturan keputusan menteri agama tugas pokok Penyuluh Agama menurut KMA No. 516 Tahun 2003 adalah melakukan dan mengembangkan kegiatan bimbingan atau penyuluhan dan pembangunan melalui bahasa agama. Artinya bahwa seorang penyuluh agama Buddha adalah mengembangkan kegiatan bimbingan atau penyuluhan melalui ajaran agama Buddha. Berpijak pada tugas pokok tersebut, maka dalam pelaksanaan tugas tersebut melekat fungsi-fungsi, yaitu, informatif dan edukatif, konsultatif, dan advokatif

Tugas dan fungsi Seorang Dhamaduta adalah menyampaikan Dhamma dengan sebaik-baiknya sehingga pendengarnya yakin akan kebenaran ajaran tersebut dan mendapatkan kebahagiaan dan kedamaian Dhammapada Bab VIII syair 1 menjelaskan bahwa daripada seribu kata yang tidak bermanfaat adalah lebih baik sepatah kata yang bermanfaat, yang dapat memberikan kedamaian kepada pendengarnya (Nyanaputra, $1998: 102)$.

Penyuluh agama Buddha dalam melaksanakan fungsinya menjalin sinergitas yang baik untuk meminimaliasi sejumlah kendala di lapangan Namun demikian, beberapa fakta yang lain terjadi di masyarakat Buddha Kabupaten Wonogiri mengalami banyak penurunan karena faktor perkawinan dan perpindahan agama. Hal tersebut diindikasikan karena kurangnya pembinaan di wilayah terkait. Selain itu, jumlah penyuluh agama Buddha yang sedikit mengakibatkan kurangnya waktu dalam memberikan 
pelayanan bimbingan kepada umat secara merata. Kurangnya waktu dalam memberikan bimbingan kepada umat secara merata mengakibatkan keyakinan umat Buddha dalam melaksanakan ajaran Buddha menurun.

Berdasarkan hasil wawancara dengan Ibu Parmi, pengurus Vihara Vihara Maitri Ratna dijelaskan bahwa jumlah umat Buddha dari tahun 1980-an sampai dengan saat ini mengalami banyak penurunan. Yang di antaranya karena pernikahan dengan pemeluk agama lain dan perindahan agama. Hasil wawancara yang dilakukan dengan umat Buddha setempat didapatkan beberapa informasi bahwa ada penyuluh agama Buddha yang ditugaskan oleh pemerintah untuk membina umat Buddha setempat. Kegiatankegiatan penyuluh yang dilakukan dinilai tidak membawa manfaat dan tidak ada perubahan demi umat Buddha sehingga berakibat umat Buddha di wilayah tersebut kurang aktif dalam mengikuti kegiatan. Selain itu masyarakat tidak berperan aktif dalam menentukan jenis kegiatan-kegiatan baru yang berbeda masyarakat umat Buddha hanya berpatokan pada penyuluh agama Buddha.

Kondisi demikian menjadi sebuah keprihatinan yang perlu dikaji lebih dalam. Dalam posisi sebagai umat minoritas seharusnya keyakinan umat harus diperkuat, tetapi justru pada kenyataannya umat tidak mendapatkan perhatian yang baik. Melihat fakta tersebut maka tidaklah mengherankan jika jumlah umat Buddha mengalami penurunan yang disebabkan oleh beberapa sebab. Secara psikologis umat Buddha akan mengalami kurang percaya diri karena jumlahnya sedikit, kurang mendapatkan perhatian dan pelayanan keagamaan yang baik dari pihak yang berkewajiban sehingga hal ini akan berdampak pada menurunnya tingkat keyakinan umat Buddha. Melihat realitas terebut sangat dibutuhkan eksistensi penyuluh agama Buddha. Melalui keberadaan penyuluh agama Buddha yang ada di setiap wilayah adalah sebagai pelestari Dhamma. Eksistensi dari seorang penyuluh sangat berguna dalam menumbuhkan dan mempertahankan keyakinan umat Buddha pada ajaran-ajaran Buddha. Umat Buddha masyarakat Vihara Maitri Ratna Kabupaten Wonogiri membutuhkan eksistensi seorang penyuluh.

\section{Metode}

Penelitian ini menggunakan metode pendekatan studi penelitian kualitatif. Metode kualitatif adalah metode penelitian yang digunakan untuk meneliti pada kondisi objek yang alamiah. Metode penelitian kualitatif sering disebut metode naturalistik karena penelitiannya dilakukan pada kondisi yang alamiah. Metode kulitatif digunakan untuk mendapatkan data yang mendalam dan mengandung makna. Makna adalah data yang 
sebenarnya data yang pasti merupakan suatu nilai dibalik data yang tampak (Sugiyono, 2013:1-3 Sementara itu lokasi yang menjadi objek penelitian adalah di Vihara Maitri Ratna Dusun Bedug, Desa Gedongrejo Kecamatan Giriwoyo Kabupaten Wonogiri.

Subjek penelitian ini adalah tempat untuk mendapatkan data atau informasi (Zulkifli, 1992: 41). Subjek yang dimaksud dalam penelitian ini adalah semua orang yang dijadikan sebagai sumber informasi dalam penelitian. Adapun subjek dalam penelitian ini adalah penyuluh agama Buddha di Vihara Maitri Ratna Dusun Bedug, Desa Gedongrejo Kecamatan Giriwoyo Kabupaten Wonogiri. Sementara itu, Muhajir (2003:3) menjelaskan bahwa objek dalam penelitian ini adalah permasalahan yang muncul dalam masyarakat.

Objek penelitian dimaksud adalah suatu masalah yang harus dipecahkan atau dibatasi penelitiannya. Objek penelitian ini adalah eksistensi penyuluh agama Buddha

Dalam penelitian ini peneliti menggunakan dua data yaitu: data primer dan data sekunder. Ratna (2010: 12) data primer adalah data yang diperoleh melalui sumber pertama. Sumber yang pertama dalam penelitian ini adalah dengan melakukan wawancara dengan beberapa umat Buddha Sementara itu, data sekunder adalah data yang diperoleh melalui sumber kedua. Data sekundernya adalah dokumen-dokumen tertulis, buku-buku teks, dan berbagai hasil pembicaraan lainnya yang secara keseluruhan berfungsi untuk mendukung data primer. Data sekender dalam penelitian ini adalah hasil wawancara dengan umat serta dokumentasi pelaksanaan wawancara. Teknik pengumpulan data dilakukan dengan 3 (tiga) cara yaitu, Wawancara mendalam (in depth interview), Observasi (pengamatan), dan Dokumentasi yang meliputi catatan-catatan dari hasil pelaksanaan penelitian.

Analisis data menurut Patton dalam buku Moleong (2007: 103) merupakan proses mengatur urutan data, mengorganisasikannya kedalam suatu pola, kategorisasi, dan satuan uraian dasar. Menurut Bogdan dan Biklen (Moleong, 2007: 248) analisis data adalah upaya yang dilakukan dengan jalan berkerja dengan data, mengorganisasi data, memilahmilahnya menjadi satuan yang dapat dikelola, mensistensisnya, mencari dan menemukan pola, menemukan apa yang penting dan apa yang dipelajari, dan memutuskan apa yang dapat diceritakan pada orang lain. Untuk menganalisis data dari hasil penelitian ini digunakan metode analisis deskriptif, yaitu data yang berkaitan dengan penelitian yang terkumpul lalu disusun dan diklasifikasikan dengan kata-kata sedemikian rupa sehingga mengambarkan objek-onjek penelitian disaat penelitian dilakukan (Suharmat, 1992: 134). Sementar itu, teknik analisis data yang 
digunakan dalam penelitian ini adalah mengacu pada konsep Milles \& Huberman (dalam Moleong, 2007:20) yaitu interaktive model yang mengklasifikasikan analisis data dalam tiga langkah yaitu, reduksi data (data reduction), penyajian data (display data) dan penarikan kesimpulan (verifikasi)

\section{Hasil Penelitian}

a) Gambaran Umum Tempat Penelitian

Berdasarkan wawancara yang dilakukan oleh penulis umat Buddha di Dusun Bedug, Desa Gedongrejo, Kecamatan Giriwoyo diperoleh informasi bahwa di wilayah tersebut lima agama yang berkembang di wilayah tersebut termasuk agama Buddha. Masuknya agama Buddha di kecamatan Giriwoyo Wonogiri yang masuk pada tahun 1970an. Pada saat itu umat Buddha belum memiliki Vihara. Pelaksanaan pujabakti dilakukan secara bergilir dari satu Dusun ke Dusun yang lain. Pembagian pujabakti pada malam minggu di Dusun Gedongrejo kemudian di Dusun Jeruk dan pindah di Dusun Ngulang kemudian Dusun Pakel, Dusun Pancuran dan Dusun Bulu. Nama-nama Dusun tersebut merupakan wilayah-wilayah yang menjadi tempat penyebaran agama Buddha. Penyebaran agama Buddha di tempat tersebut mendapat respon yang sangat tinggi dari masyarakat. Hal ini terbukti pada tahun-tahun tersebut jumlah umat
Buddha sangat banyak mencapai ratusan Kepala Keluarga.

Perkembangan tersebut mendapatkan perhatian dari para tokoh umat Buddha dan pemerintah. Sehingga pada tahun 1978 ditempat tersebut dibangun vihara yang kecil dengan menggunakan tanah hibah dari Bapak Kariman. Kemudian hibah tersebut diganti rugi oleh umat Buddha yang kemudian di bangun Vihara yang lebih besar. Tokoh umat Buddha yang sering datang memberikan penyuluhan pada masa itu adalah Romo Harjanto, romo Wardo, Romo Warno.

Perkembangan selanjutnya di wilayah tersebut agama Buddha mengalami kesulitan dalam hal pencarian akta pernikahan. Banyak umat yang menikah dengan tatacara agama Buddha tetapi tidak mendapat surat nikah. Dampak dari kondisi tersbut banyak umat yang tidak mau mengurus dan akhirnya pindah agama. Hal tersebut mengakibatkan berkurangnya jumlah umat Buddha di Wilayah Dusun Bedug, Desa Gedongrejo Kecamatan Giriwoyo Wonogiri Jawa Tengah.Tata kehidupan masyrakat umat Buddha di Dusun Bedug, Desa Gedongrejo Kecamatan Giriwoyo adalah menjadi seorang petani. Selain menjadi seorang petani terdapat umat yang menjadi seorang pedagang dan menjadi seorang peternak.

b) Eksistensi Penyuluh Agama Buddha 
Berdasarkan hasil wawancara dilakukan oleh penulis pada tokoh masyarakat umat Buddha di Vihara Maitri Ratna Dusun Bedug, Desa Gedongrejo, Kecamatan Wonogiri Jawa Tengah terkait dengan eksistensi penyuluh . Berdasarkan pada hasil wawancara dengan Bapak Widodo yang menjelaskan bahwa eksistensi penyuluh agama Buddha di Vihara Maitri Ratna, Dusun Bedug, Desa Gedongrejo, Kecamatan Giriwoyo, Kabupaten Wonogiri Jawa Tengah jarang di lakukan oleh para penyuluh. Hal tersebut dikarenakan sedikitnya jumlah penyuluh agama Buddha yang ada di kabupaten Wonogiri. Selain itu karena jarak yang jauh dan sedik menyulitkan bagi para penyuluh. Meskipun demikian keyakinan pada ajaran masih sangat tinggi. Hal ini dapat dilihat apabila ada pembinaan antusias umat buddha vihara tersebut

Kemampuan seorang penyuluh agama Buddha sangat dibutuhkan untuk mengembangkan, membimbing umat Buddha di Vihara Maitri Ratna, Dusun Bedug, Desa Gedongrejo, Kecamatan Giriwoyo, Kabupaten Wonogiri Jawa Tengah. Hal tersebut dikarenakan dalam penyampaian Dhamma oleh penyuluh lebih mengena dibandingkan dengan jika hanya umat biasa yang memberikan Dhamma. Seorang penyuluh umat Buddha memiliki kemampuan dalam menggerakan umat Buddha di Vihara Maitri Ratna, Dusun
Bedug, Desa Gedongrejo, Kecamatan Giriwoyo, Kabupaten Wonogiri Jawa Tengah dengan demikian seorang penyuluh memiliki kemampuan untuk memberi motivasi kepada umat untuk terus maju dan mempertahankan keyakinan. Selain itu didukung dengan perilaku yang ditunjukkan oleh seorang penyuluh yang baik kepada umat menambah keyakinan kami kami pentingnya seorang figur untuk jadi penyuluh.

Adanya penyuluh umat Buddha pada saat sekarang walaupun kedatangan tidak tentu tetapi dapat membantu masyarakat dalam mencari surat-surat misalnya mengurus surat pernikahan dan sebagainya. Umat Buddha di Vihara Maitri Ratna, Dusun Bedug, Desa Gedongrejo, Kecamatan Giriwoyo, Kabupaten Wonogiri Jawa Tengah yang masih bertahan berkeyakinan ajarann Buddha berjumlah 30 sampai dengan 40 kepala keluarga.

Selanjutnya peneliti melakukan wawancara pada tanggal 15 Mei 2016 dengan Bapak Sadimin hasil wawancara dengan beliau adalah sebagai berikut

Penyuluhan kadang kala wonten soal keyakinan umat ingkang sak mangke wonten muniko penuh keyakinan nanging pelaksanaane durung. penyuluhan kurang dan dan bimbingan kurang lha muniko kirang kemajuan dados pengetahuanya terbatas kadang kadang kulo saget mendet sakeng buku buku bilih mngke buku kulo saget wedaraken nek mboten kulo 
wedaraken kulo waos mngke dibahas barang enten vihara.

Berdasarkan keterangan di atas dapat disimpulkan bahwa adanya penyuluh jarang. Kondisi tersebut mengakibatkan umat Buddha di Vihara Maitri Ratna, Dusun Bedug, Desa Gedongrejo, Kecamatan Giriwoyo, Kabupaten Wonogiri Jawa Tengah belajar dan diskusi sendiri dengan buku-buku yang ada di Vihara dan dibahas secara bersama-sama pada tanggal 15 Juni 2016.

Nek wonten kesempatan kulo ngisi paleng mboten nggeh 1 wulan pin 2 ngantos 3. Ora ketang sekecap rong kecap mesti ngisi. puniko keyakinan menunjang kehidupan nggeh puniko kulo sesaget maringi penyuluhan meniko wonten hubunganipon kehidupan sehari hari contonipun nggeh menungso niko mboten saget gesang kiambak niki antar agama saling membantu dan saling menunjang.

Terkadang yang dilakukan oleh umat Buddha di Vihara Maitri Ratna, Dusun Bedug, Desa Gedongrejo, Kecamatan Giriwoyo, Kabupaten Wonogiri Jawa Tengah adalah diisi oleh umat sendiri. Hal ini dikarenakan sebagai manusia harus saling membantu antara yang satu dengan yang lainnya. Selanjutnya pada tanggal 15 Agustus 2016 Bapak Sadimin Menjelaskan:

Kulo panjenengan saget gesang nggeh puniko nedho tetumbukan iku nunjukke yen urip iki bebarengan opo meneh wong indonesia banyak agama banyak suku ini kudu bersatu meniko kulo cocoaken kalio lambang negara bilih teng mriki pas ngrehap vihara puniko sedoyo umat membantu kerja.

Manusia hidup makan tumbuhtumbuhan itu menunjukkan bahwa kehidupan ini ada hidup bersama. Berbeda-beda tetapi tetap satu jua. Harus selalu membantu dalam segala hal contohnya jika memperbaiki vihara dilakukan secara gotong royong. Selanjutnya Bapak sadimin menjelaskan bahwa masih harus dibimbing sehingga memiliki kemajuan yang luar biasa. Selanjutnya wawancara dilakukan dengan ketua Vihara Maitri Ratna Bapak Sutino. Hasil wawancara dengan ketua vihara adalah sebagai berikut:

Sutino menjelaskan eksistensi penyuluh agama Buddha di Vihara Maitri Ratna, Dusun Bedug, Desa Gedongrejo, Kecamatan Giriwoyo, Kabupaten Wonogiri Jawa Tengah. Keberadaan penyuluh khusunya di agama buddha masih sangat jarang hal tersebut minimnya jumlah penyuluh yang ada. Selain itu dimungkinkan karena jarak dari tempat para penyuluh sangat jauh sehingga hal tersebut terjadi. Hal tersebut mengakibatkan kemantapan dalam hal keyakinan umat Buddha di Vihara Maitri Ratna berbeda. Generasi Tua dalam hal keyakinan sangat tinggi sedangkan untuk generasi muda melemah ditambah dengan sedikitnya pendidikan yang diperoleh di lembaga sekolah termasuk sekolah minnggu. 
Keyakinan umat pada kebenaran ajaran sudah tidak diragukan lagi. Masyarakat hanya berfikir untuk mempertahankan keyakinan ajaran Buddha pada generasi muda. Kurangnya jumlah penyuluh agama Buddha memberikan dampak yang kurang baik bagi perkembangan agama Buddha. Pelaksanaan tugas dari seorang penyuluh berperan penting. Keberadaan penyuluh memberikan motivasi yang sangat besar pada umat. Melalui motivasi tersebut umat Buddha akan mempertahankan keyakinannya. Hal ini ditunjukkan dalam keaktifan umat pada saat ada pembinaan penyuluh. Kehadiran umat pada saat ada penyuluh bisa seluruh umat hadir ke Vihara, tetapi pada saat biasa hanya sebagian saja umat yang datang ke Vihara.

Kompetensi yang dimiliki oleh penyuluh agama Buddha berpengaruh pada cara penyuluh dalam menyampaikan dhammadesana di Vihara Maitri Ratna, Dusun Bedug, Desa Gedongrejo, Kecamatan Giriwoyo, Kabupaten Wonogiri. Penyampaian Dhammadesana seorang penyuluh di vihara yang menarik dan mampu memberikan motivasi dalam kehidupan masyarakat umat Buddha. Hal tersebut menunjukkan bahwa seorang penyuluh memiliki intelektual yang tinggi yang selalu berorientasi pada masa yang akan datang.

Selanjutnya, wawancara pada tanggal 22 dan 23 Juli 2016 dengan Ibu Parmi. Hasil wawancara dengan Ibu Parmi yang menjelaskan bahwa keberadaan panyuluh atau eksisstensi penyuluh agama Buddha sekarang dengan pada jaman dahulu berbeda. Pada zaman dulu hampir setiap minggu ada penyuluh datang ke vihara. Sekarang penyuluh jarang datang paling 2 sampai 3 bulan sekali baru ada penyuluh. Terkait dengan keyakinan pada ajaran saya tetap berkeyakina pada ajaran Sang Buddha. Ada atau tidaknya seorang penyuluh saya tetap berkeyakinan pada ajaran. Keyakinan pada kebenaran dhamma sudah tidak ditawar lagi. Hanya yang saya khawatirkan bahwa generasi muda yang kurang memiliki pondasi keyakinan agama yang kuat. Hal tersebut dikarenakan kurangnya layananan pendidikan yang diperoleh di sekolah.

Pelaksanaan tugas seorang Dharmaduta atau penyuluh agama di Vihara Maitri Ratna, sangat dibutuhkan, hal tersebut mengingat. Adanya seorang penyuluh akan membantu masyarakat dalam mengarahkan dan membimbing umat Buddha tetap berpegang tegeh pada ajaran Buddha. Keberadaan/eksistesi seorang penyuluh menbuat di Vihara Maitri Ratna, memberikan motivasi pada umat melalui motivasi yang diberikan umat tetap memiliki semangat yang tinggi walupun pada saat ini hanya memiliki jumlah umat Buddha yang sedikit.

c) Kompetensi Penyuluh Agama Buddha 
Sosialisasi kepenyuluhan agama Buddha jarang dilakukan oleh para penyuluh. Kondisi tersebut tidak mengurangi kepercayaan mereka sebagai umat akan hukum-hukum kesunyataan mulia mendasari umat berpegang teguh pada Dhamma. Keyakinan akan kebenaran menjadi salah satu kunci pokok dalam kehidupan di masyarakat. Hal tersebut selaras dengan yang dijelaskan (Tahin Suhaimin 2015:10) dalam buddhisme keyakinan adalah kepercayaan berdasar pada kebijaksanaan, keyakinan adalah kepercayaan mengdalikan hidup.

Kemampuan seorang penyuluh agama Buddha sangat dibutuhkan untuk mengembangkan, membimbing umat Buddha Hal tersebut selaras dengan peraturan KMA Nomor : 516 Tahun 2003 tentang Petunjuk Teknis Pelaksanaan Jabatan Fungsional Penyuluh Agama dan Angka Kreditnya, Penyuluh Agama adalah : "Pegawai Negeri Sipil yang diberi tugas, tanggung jawab dan wewenang secara penuh oleh pejabat yang berwenang untuk melakukan kegiatan bimbingan keagamaan dan penyuluhan pembangunan melalui bahasa agama. Seorang penyuluh umat buddha memiliki kemampuan dalam menggerakan umat buddha Sama halnya dengan yang dijelaskan dalam Mahavagga, Vinaya Pitaka (Horner, 2000: 28). Para bhikkhu, ajarkanlah Dhamma yang indah pada awalnya, indah pada pertengahannya, indah pada akhirnya. Jelaskanlah dengan semangat dan secara keseluruhan. Terdapat makhlukmakhluk dengan sedikit debu di mata mereka, siapa yang tidak mendengar Dhamma, maka akan hancur, tetapi jika mereka mendengarkan Dhamma, mereka akan berkembang. Selain itu didukung dengan perilaku yang ditunjukkan oleh seorang penyuluh yang baik kepada umat menambah keyakinan. Hal lain yang harus diperhatikan adalah pentingnya seorang figur untuk jadi penyuluh.

Selanjutnya Bapak Sadimin menjelaskan bahwa masih harus dibimbing sehingga memiliki kemajuan yang luar biasa yang harus diawali dari dalam diri sendiri. Selaras dengan hal tesebut Sri Dhammananda menjelaskan bahwa, setiap individu harus mampu mengembangkan pemahaman dan pengelihatan (2003: 64). Bapak Sutino menjelaskan keberadaan penyuluh memantapan dalam hal keyakinan umat Buddha di Vihara Maitri Ratna menjadi salah satu faktor penggerak. Hal yang sama dijelaskan oleh (Purwanto, 2007). Motivasi mengandung tiga komponen penting, yaitu menggerakkan, mengarahkan, dan menopang tingkah laku manusia.

Kompetensi seorang penyuluh menjadi hal yang sangat berharga dalam memajukan dan mengembangkan umat Buddha di wilayah tersebut. Kompetensi menurut Rotwell dalam Burhan (2011) dapat dibedakan menjadi 
empat, yaitu: Kompetensi Teknis (Teknical Competence), yaitu kompetensi mengenai bidang yang menjadi tugas pokok organisasi; Kompetensi Manajerial (Managerial Competence) adalah kompetensi yang berhubungan dengan berbagai kemampuan manajerial yang dibutuhkan dalam menangani tugas-tugas organisasi; Kompetensi Sosial (Social Competence) yaitu kemampuan melakukan komunikasi yang dibutuhkan oleh organisasi; Kompetensi Intelektual/Strategik (Intelektual/Strategic Competence) yaitu kemampuan untuk berfikir secara stratejik dengan visi jauh kedepan.

d) Upaya Mempertahankan Keyakinan Umat Buddha

Keberadaan penyuluh harus memiliki kemantapan dalam hal keyakinan umat Buddha di Vihara Maitri Ratna menjadi salah satu faktor penggerak. Motivasi mengandung tiga komponen penting, yaitu menggerakkan, mengarahkan, dan menopang tingkah laku manusia. Eksistensi diartikan sebagai keberadaan, dalam hal ini adalah keberadaan penyuluh agama buddha di Vihara Maitri Ratna, Dusun Bedug, Desa Gedongrejo, Kecamatan Giriwoyo, Kabupaten Wonogiri Jawa Tengah. Keberadaan penyuluh di vihara tersebut tidak rutin dilaksanakan. Hal tersebut dikarenakan sedikitnya jumlah penyuluh yang ada di Kabupaten Wonogiri khususnya di
Dusun Bedug, Desa Gedongrejo, Kecamatan Giriwoyo. Keberadaan panyuluh atau eksisstensi penyuluh agama Buddha sebagai sosok panutan umat Buddha. Priastana (2005: 10) menjelaskan komunikator Dhamma yang efektif

Kredibilitas sumber yang berkenaan dengan kecakapan dan kepercayaan Dhammadūta yaitu pengetahuan, keahlian dan pengalaman yang relevan dengan topik, pesan yang disampaikan. Melalui kemampuan dan keahlian yang dimiliki oleh penyuluh diharapkan mampu memberikan wawasan yang luas akan ajaran Buddha Dhamma. Hal tersbut harus didukung oleh kepribadian yang dimiliki oleh seorang penyuluh. Seorang penyuluh terkadang dianggap sebagai orang yang sudah memiliki kemahiran dalam wawasan Dhamma dan Vinaya.

Kepribadian yang harus dimiliki oleh seorang penyuluh adakah sifat terbuka dan sikap pengabdian yang harus dimiliki Dhammadūta. Sifat tersebut harus dikembangkan oleh seorang penyuluh kepada umat. Tujuan dari pengembangan sifat ini adalah agar para umat tidak memiliki sifat yang melekat kuat terhadap materi. Melalui pengembangan tersebut diharapkan agar umat memiliki kesederhanaan dalam hidup. Selanjutnya penyuluh Dhammadūta mempunyai pandangan yang luas dan tidak berpandangan secara eksklusif. 
Empati yaitu Dhammadūta mempunyai kepekaan berkaitan dengan kebahagiaan. Simpati yaitu Dhammadūta menempatkan diri kita pada posisi orang lain (menyangkut kesedihan, penderitaan). Keterampilan berkomunikasi ketrampilan berbicara, menulis, membaca, mendengarkan dan berfikir. Fungsi dan peran sorang penyuluh yang kurang berjalan maksimal tidak menjadikan umat Buddha Vihara Maitri Ratna untuk belajar tentang pengetahuan Dhmma. Melalui pengetahuan umat Buddha di Wilayah tersebut mampu mempertahankan keyakinan ajaran Buddha. Keyakinan dimiliki oleh umat merupakan salah satu bentuk usaha dari umat untuk mempertahankan ajaran Buddha.

Pemahaman tentang hukum-hukum kebenaran yang diajarkan oleh sang Buddha menjadi dasar yang paling kuat dalam mempertahankan keyakinan. keyakinan akan kebenaran menjadi salah satu kunci pokok dalam kehidupan di masyarakat. Keyakinan adalah kepercayaan berdasar pada kebijaksanaan, keyakinan adalah kepercayaan mengdalikan hidup. Artinya umat tidak akan terjerumus dalam hal yang salah dan akan tetap mempertahankan ajarannya kebenaran jika berdasar pada kebijaksanaa. Bijaksana dalam kebenaran adalah mampu membedakan antara benar atau tidak benar, salah atau tidak salah sehingga umat tidak memiliki pandangan yang keliru (Sakkaya Ditthi).
Kemampuan untuk memiliki kebijaksanaan ditunjukkan dengan cara seorang penyuluh agama Buddha untuk mengembangkan, membimbing umat Buddha di Vihara Maitri Ratna, Dusun Bedug, Desa Gedongrejo, Kecamatan Giriwoyo, Kabupaten Wonogiri Jawa Tengah. Melalui bimbingan keagamaan yang diberikan oleh seorang penyuluh umat atau masyarakat. Pengembangan dan bimbingan agama merupakan salah satu hal pokok yang menjadi kompetensi Penyuluh agama Buddha dengan melalui kemampuan-kemampuan tersebut, maka sangat mungkin umat akan mampu mempertahankan keyakinannya pada ajaran kebenaran.

Selain kompetensi di atas seorang penyuluh umat buddha memiliki kemampuan dalam menggerakan umat. Kemampuan dalam memberikan dorongan dan ajakan kepada umat menjadi hal yang penting sebagai bentuk motivasi. Salah satu contoh yang di ditunjukkan oleh Buddha agar para Bhikkhu bersemangat dalam mengembang tugas sebagai pelestari dhamma Para Bhikkhu, ajarkanlah Dhamma yang indah pada awalnya, indah pada pertengahannya, indah pada akhirnya. Jelaskanlah dengan semangat. Terdapat makhluk-makhluk dengan sedikit debu di mata mereka, siapa yang tidak mendengar Dhamma, maka akan hancur, tetapi jika mereka mendengarkan Dhamma, mereka 
akan berkembang. Kemampuan dalam menggerakkan umat untuk berkembang dan terus berkembang adalah langkah untuk mempertahankan keyakinan pada kebenaran sejati.

Kompetensi yang lain yang harus dimiliki oleh seorang penyuluh agama Buddha Kompetensi Teknis (Teknical Competence), yaitu kompetensi mengenai bidang yang menjadi tugas pokok organisasi; Kompetensi Manajerial (Managerial Competence) adalah kompetensi yang berhubungan dengan berbagai kemampuan manajerial yang dibutuhkan dalam menangani tugas-tugas organisasi; Kompetensi Sosial (Sicial Competence) yaitu kemampuan melakukan komunikasi yang dibutuhkan oleh organisasi; Kompetensi Intelektual/Strategik (Intelektual/Strategic Competence) yaitu kemampuan untuk berfikir secara stratejik dengan visi jauh kedepan.

\section{Kesimpulan}

Eksistensi seorang penyuluh di Vihara Maitri Ratna Dusun Bedug, Desa Gedongrejo, Kecamatan Giriwoyo, Wonogiri Jawa Tengah jarang dilakukan. Kondisi demikian mempengaruhi umat dalam keaktifan di Vihara. Selain itu, karena jarangnya penyuluhan banyak mengakibatkan sebagian umat tidak memahami tentang ajaran Buddha. Kondisi demikian seharusnya tidak terjadi karena seorang penyuluh memiliki peran yang sangat penting dalam kemajuan dan perkembangan ajaran dalam masyarakat khususnya di Vihara Maitri Ratna Dusun Bedug, Desa Gedongrejo, Kecamatan Giriwoyo Wonogiri Jawa Tengah.

Eksistensi penyuluh agama Buddha sangat dibutuhkan oleh umat Buddha. Eksistensi penyuluh sebagai penggerak umat atau motivasi dalam mempertahankan keyakinan ajaran Buddha Dhamma. Seorang penyuluh memiliki tiga komponen penting dalam fungsi dan perannya sebagai seorang penyuluh, yaitu menggerakkan, mengarahkan, dan menopang tingkah laku manusia.

Melalui hal tersebut seorang penyuluh mengembangkan kredibilitas, kepribadian,mempunyai pandangan yang luas,Empatidan simpati. Keterampilan berkomunikasi ketrampilan berbicara, menulis, membaca, mendengarkan dan berfikir. Fungsi dan peran sorang penyuluh yang kurang berjalan maksimal tidak menjadikan umat Buddha Vihara Maitri Ratna untuk belajar tentang pengetahuan Dhmma. Pemahaman tentang hukum-hukum kebenaran yang diajarkan oleh sang Buddha menjadi dasar yang paling kuat. Keyakinan adalah kepercayaan berdasar pada kebijaksanaan, keyakinan adalah kepercayaan mengdalikan hidup berdasar pada kebijaksanaa. 
Kompetensi yang lain yang harus dimiliki oleh seorang penyuluh agama Buddha Kompetensi Teknis (Teknical Competence), yaitu kompetensi mengenai bidang yang menjadi tugas pokok organisasi; Kompetensi Manajerial (Managerial Competence) adalah kompetensi yang berhubungan dengan berbagai kemampuan manajerial yang dibutuhkan dalam menangani tugas-tugas organisasi; Kompetensi Sosial (Sicial Competence) yaitu kemampuan melakukan komunikasi yang dibutuhkan oleh organisasi; Kompetensi Intelektual/Strategik (Intelektual/Strategic Competence) yaitu kemampuan untuk berfikir secara stratejik dengan visi jauh kedepan.

\section{Daftar Pustaka}

Alex Lanur. (1988). Filsafat Manusia Driyarkara, Basis, Basis, no 09. Th. XXXVII. Jakarta: PT. Pembangunan.

Daud. (2015). Pelaksanaan Penyuluh Agama dalam Pembinaan Umat. Artikel Ilmiah BDK Palembang.

Departemen Agama RI. (2002) Buku Petunjuk Teknis Jabatan Fungsional Penyuluh Agama Departemen Agama RI Direktorat Jenderal Kelembagaan Agama Buddha Bagian Proyek Peningkatan Tenaga Keagamaan Penyuluh Agama Tahun 2002.

Kementrian Agama. (2006). Pedoman Juklak dan Juknis Penyuluh Agama Fungsional: Jakarta.Kementrian Agama
Kementrian Agama RI. (2001). Petunjuk Teknis Jabatan Fungsional Penyuluh Agama Islam, Ditjen Bimas Islam dan Urusan Haji Proyek Bimbingan dan Dakwah Agama Islam Pusat, Jakarta.

Kementrian Agama. (2006). Pedoman Juklak dan Juknis Penyuluh Agama Fungsional : Kementrian Agama. Jakarta

Keputusan Menteri Agama Republik Indonesia dan Kepala Badan Kepegawaian Negara (BKN) Nomor: 574 Tahun 1999 Nomor: 178 Tahun 1999 tentangPetunjuk Pelaksanaan Jabatan Fungsional Penyuluh Agama dan Angka Kreditnya, 1999.

KMA Nomor : 516 Tahun 2003 tentang Petunjuk Teknis Pelaksanaan Jabatan Fungsional Penyuluh Agama dan Angka Kreditnya.

Moleong, Lexy, J (2007). Metodologi penelitian kualitatif. Bandung: Remaja Rosdakarya.

Mukti, K.W. (2003). Wacana Buddha Dhamma. Jakarta: Yayasan Dharma Pembangunan Sangha Agung Indonesia.

Nyanaputra, Bhikkhu. (1998). Dhammaduta. Jakarta: Pustaka Ekayana.

Noeng Muhajir. (2003). Metode Penelitian Kualitatif. Edisi IV. Yogyakarta. Rake Sanasin

PMA No. 791 tahun 1985 tentang Honorarium Bagi Penyuluh Agama.

Sri Dhammananda. (2003). Keyakinan Umat Buddha Buku Standar Wajib Baca. Jakarta: Ehipassiko.

Sugiyono. (2013). Memahani Penelitian Kualitatif. Bandung: Alfabeta.

Sugiyono. (2010). Metode Penelitian Kuantitatif, Kualitatif dan $R \& D$. Bandung: Alfabeta 
Taidin, Suhaimin. (2015). Keajaiban Keyakinan Diri. ugmc.bizland.com.

Widyadharma.S. (1979). Riwayat Hidup Buddha Gautama. Jakarta: Yayasan. Dana Pendidikan Buddhis Nalanda.
Winarno Suharmat. (1992). Pengantar Penelitian Ilmiah. Bandung: Tarsito.

Zulkifli, (1992). Psikologi Perkembangan. Bandung. PT. Remaja Rosda Karya. 